\title{
Комбінований відеоендоскопічно-черезшкірний доступ у хірургічному лікуванні інфікованого гострого некротичного панкреатиту
}

\author{
I. В. Хомяк ${ }^{1}$, М. В. Костилев ${ }^{1}$, О. В. Ротар ${ }^{2}$, I. С. Терешкевич ${ }^{1}$, В. І. Ротар ${ }^{2}$, А. І. Хомяк ${ }^{1}$
}

${ }^{1}$ Національний інститут хірургії та трансплантології імені О. О. Шалімова НАМН України, м. Київ,

²Буковинський державний медичний університет, м. Чернівці

\section{Combined videoendoscopic-transcutaneous approach in surgical treatment of the infected acute necrotic pancreatitis}

\author{
I. V. Khomyak ${ }^{1}$, M. V. Kostylev ${ }^{1}$, O. V. $\operatorname{Rotar}^{2}$, I. S. Tereshkevych ${ }^{1}$, V. I. $\operatorname{Rotar}^{2}$, A. I. Khomyak ${ }^{1}$ \\ ${ }^{1}$ Shalimov National Institute of Surgery and Transplantology, Kyiv \\ ${ }^{2}$ Bukovyna State Medical University, Chernivtsi
}

\begin{abstract}
Реферат
Мета. Оцінити ефективність запропонованого комбінованого відеоендоскопічно-черезшкірного доступу в хірургічному лікуванні інфікованого гострого некротичного панкреатиту (ГНП)

Матеріали і методи. Черезшкірні діапевтичні пункції та дренування застосовані в 74 паціентів (контрольна група), у 23 (основна група) з приводу лікування поширених інфікованих патологічних вогнищ використаний комбінований відеоендоскопічно-черезшкірний доступ.

Результати. Застосування діапевтичних втручань дозволило відтермінувати виконання оперативного втручання до 25 - 30-ї доби захворювання в усіх пацієнтів основної групи та у 82,7\% - контрольної. В основній групі відзначене зменшення необхідності виконання лапаротомної некрсеквестректомії на 29,1\%, інвазивних втручань - на 46,1\%, смертності - на 2,9\%.

Висновки. Використання комбінованого доступу забезпечило зменшення частоти виконання інвазивних втручань, зокрема лапаротомної некрсеквестректомії.

ключові слова: інфікований гострий некротичний панкреатит; мініінвазивні втручання; ехо-відеоендоскопія.

Abstract

Objective. To estimate the efficacy of the proposed combined videoendoscopic transcutaneous access in surgical treatment of the infected acute necrotic pancreatitis.

Materials and methods. Transcutaneous diapeutic punctures and draining were applied in 74 patients (control group), and in 23 (main group) for treatment of spread infected pathological foci, using combined videothoracoscoopic transcutaneous access.

Results. Application of diapeutic interventions have permitted to defer the operative intervention performance up to 25 - 30th day of the disease in all patients of the main group and in $82.7 \%$ - in a control one. In the main group a reduction of necessity in laparotomic necrsequestrectomy performance by $29.1 \%$, of the invasive interventions - by $46.1 \%$, and for mortality rate - by $2.9 \%$ was noted.

Conclusion. Application of combined access have guaranteed the reduction of the invasive interventions performance rate, including laparotomic necrsequestrectomy.

Keywords: infected acute necrotic pancreatitis; miniinvasive interventions; echo-videoendoscopy.
\end{abstract}

Гострий панкреатит (ГП) - первинно-асептичний гострий запальний процес у підшлунковій залозі (ПЗ) 3 різною тяжкістю ураження парапанкреатичних тканин і віддалених органів. Частота ГП щороку збільшується на 2,5 - 3,1\%, становить від 15 до 70 на 100000 населення в країнах Европи та Північної Америки [1]. Загальна тривалість лікування хворого в стаціонарі становить у середньому 7 днів. Це свідчить, що в більшості пацієнтів перебіг захворювання легкий, добре піддається лікуванню. Проте у 20\% пацієнтів виникають тяжкі некротичні форми ГП з органною недостатністю $(\mathrm{OH})$, тривалістю понад 48 год, при цьому локальні ускладнення є негативними прогностичними факторами перебігу захворювання [2]. Майже 50\% хворих вмирають протягом перших 7 діб після госпіталізації, більшість - у перші 3 доби. У пацієнтів за тяжкого ГНП, які переживають першу фазу хворо- би, високий ризик вторинного інфікування вогнищ панкреонекрозу. Смертність хворих за інфікованого ГНП 3 ОН досягає 30 - 40\%, тому його виникнення є абсолютним показанням до оперативного втручання [3]. Сучасна хірургічна тактика лікування інфікованого ГНП основана на широкому впровадженні мініінвазивних технологій: черезшкірної та ендоскопічної санації під контролем ультразвукового дослідження (УЗД) або комп'ютерної томографії (КТ), методів дренування гнійно-некротичних вогнищ з використанням мінілюмбо- або мінілапаротомічного доступу за допомогою лапароскопа або нефроскопа [4, 5]. Мініінвазивні втручання використовують як самостійний хірургічний метод лікування при відмежованих вогнищах панкреонекрозу та інфікованих псевдокістах ПЗ або як етап підготовки до виконання некрсеквестректомії (step-up approach), що від- 
повідає основним принципам міжнародних рекомендацій ІАР/АРА з ГНП $[6,7]$.

Мета дослідження: Оцінити ефективність запропонованого комбінованого відеоендоскопічного черезшкірного доступу в хірургічному лікуванні інфікованого ГНП.

\section{Матеріали і методи дослідження}

Проаналізовані результати хірургічного лікування 97 хворих з приводу інфікованого ГНП за період 20122017 рр. Жінок було 43 (44,3\%), чоловіків - 54 (55,7\%), вік хворих від 18 до 78 років, у середньому (48 \pm 1 ) рік (див. таблицю). Черезшкірні діапевтичні пункції та дренування застосовані у 74 пацієнтів (контрольна група), у 23 хворих (основна група) для лікування поширених інфікованих патологічних вогнищ, що прилягали до стінки шлунка або дванадцятипалої кишки, використаний комбінований відеоендоскопічно-черезшкірний доступ. Першим етапом під контролем УЗД встановлювали черезшкірний дренаж, другим етапом - за допомогою ехо-відеоендоскопа здійснювали пункцію утворення через стінку шлунка або дванадцятипалої кишки та за необхідності його внутрішнє дренування з використанням пластикових або металевих стентів. Групи репрезентативні за віком, статтю хворих, індексом маси тіла (IMT), ОН під час госпіталізації, тяжкістю стану за шкалою АРАСНЕ II, типом та поширенням патологічних вогнищ ГНП. Діагноз ГНП встановлювали на основі аналізу даних анамнезу, клінічних, лабораторних (активність амілази крові й сечі) та інструментальних (УЗД, контрастно-підсилена комп'ютерна томографія - КТ) методів дослідження. Тяжкість ГНП оцінювали за рекомендаціями групи з перегляду класифікації ГП (Атланта, 1992) інтернаціонального консенсусу (2012) [8] за наявності транзиторної або постійної ОН та за шкалою АРАСНЕ II (Acute Physiology and Chronic Health Evaluation II). Для визначення ОН оцінювали функції дихальної, серцево-судинної систем і нирок за модифікованою шкалою
Marshall, неврологічну недостатність - за шкалою ком Глазго. Усім хворим проводили індивідуально підібрану консервативну терапію, основними принципами якої були: знеболювання, корекція порушень центральної гемодинаміки та периферійного кровообігу, раннє ентеральне харчування, адекватне білково-енергетичне забезпечення, профілактика гнійної інфекції, пригнічення секреторної активності П3, дезінтоксикаційна терапія, корекція імунних розладів, профілактика утворення стресових виразок, гепатопротекція. Діагностували інфікування вогнищ панкреонекрозу за ознаками синдрому системної запальної відповіді (ССЗВ), даними КТ, бактеріологічного дослідження, тесту з прокальцитоніном. у більшості пацієнтів обох груп діагностовані по два і більше патологічних утворення, діаметром 6 - 12 см. Черезшкірний доступ до патологічних вогнищ обирали за даними контрастно-підсиленої КТ, у більшості пацієнтів пункцію проводили через ліву поперекову ділянку. Використовували також доступи через печінку, шлунково-селезінкову й шлунково-ободову зв'язки, малий сальник, транслюмбальний. Під час лікувальної пункції максимально видаляли вміст, багаторазово промивали порожнину розчинами антисептиків, зокрема озонованим ізотонічним розчином натрію хлориду, бетадином.

Для оцінювання ефективності хірургічного лікування хворих з приводу ГНП визначали: вперше виявлену після операції ОН, тривалість інтенсивної терапії, інфекційні і післяопераційні ускладнення, післяопераційну летальність. Статистичний аналіз проведений $з$ використанням t-критерію Стьюдента для оцінювання безперервних величин, U Мана-Уітні-Вілкоксона - для категорованих показників, $\chi^{2}$ - для якісних показників.

\section{Результати}

Усім пацієнтам основної групи та 38 - контрольної групи патологічні вогнища дренували за методикою Сельдингера, встановлювали силіконові дренажі вели-

\begin{tabular}{|c|c|c|}
\hline \multicolumn{3}{|c|}{ Клінічна характеристика хворих на інфікований гнП } \\
\hline \multirow{2}{*}{ Показник } & \multicolumn{2}{|c|}{ Величина показника в групах } \\
\hline & контрольній (n=74) & основній $(n=23)$ \\
\hline Вік, років $(\bar{x} \pm m)$ & $48 \pm 3$ & $45 \pm 2$ \\
\hline Стать, чол/жін,\% & $70 / 30$ & $61 / 39$ \\
\hline $\mathrm{IMT}, \mathrm{Kr} / \mathrm{M}^{2}(\overline{\mathrm{x}} \pm \mathrm{m})$ & $27,2 \pm 2,1$ & $26,4 \pm 1,8$ \\
\hline Тяжкість за шкалою АPACHE II, балів ( $\bar{x} \pm$ m) & $12,5 \pm 0,41$ & $11,4 \pm 0,74$ \\
\hline \multicolumn{3}{|l|}{ Місцеві ускладнення, абс. (\%) } \\
\hline гострі некротичні скупчення рідини & $35(47,3)$ & $9(39,1)$ \\
\hline відмежований некроз & $39(52,7)$ & $14(60,9)$ \\
\hline \multicolumn{3}{|c|}{ Поширення панкреонекрозу, \% тканини ПЗ, абс (\%) } \\
\hline до 30 & $20(27,0)$ & $4(17,4)$ \\
\hline $30-50$ & $29(39,2)$ & $11(47,8)$ \\
\hline більше 50 & $25(33,8)$ & $8(34,8)$ \\
\hline \multicolumn{3}{|l|}{ ОН при госпіталізації, абс. (\%) } \\
\hline транзиторна (до 48 год) & $7(9,5)$ & $5(21,7)$ \\
\hline постійна (понад 48 год) & $27(36,5)$ & $8(34,8)$ \\
\hline Кількість інвазивних втручань, $(\bar{x} \pm \mathrm{m})$ & $2,46 \pm 0,14$ & $1,35 \pm 0,17^{*}$ \\
\hline Лапаротомна некрсеквестректомія, абс. \% & $28(37,8)$ & $2(8,7)^{*}$ \\
\hline С-реактивний протеїн, мкг/мл ( $\bar{x} \pm \mathrm{m})$ & $241 \pm 21,2$ & $212 \pm 16,3$ \\
\hline Тривалість лікування у стаціонарі $(\bar{x} \pm \mathrm{m})$ & $32 \pm 2$ & $27 \pm 4$ \\
\hline Смертність, \% & 2,7 & - \\
\hline * - різниця по & знянні з такими у кон & $p<0,05)$ \\
\hline
\end{tabular}


кого діаметра. Одночасно під контролем ехо-відеоендоскопа здійснювали пункцію через стінку шлунка або дванадцятипалої кишки в 10 пацієнтів основної групи, дренування патологічних вогнищ - у 13. Для дренування використовували два пластикові стенти типу «double pig-tail» діаметром 6 - 8 Fr (у 5 хворих), встановлювали цистоназальний дренаж 3 подальшим локальним лаважем 3 використанням антибактеріальних препаратів (у 4), виконували трансмуральну панкреатонекрсеквестректомію через встановлений металевий стент (пат. України 107326, у 4 паціентів). За недостатньої ефективності встановленого під контролем УЗД черезшкірного дренажу в 6 хворих контрольної групи та в 1 - основної з інфікованими вогнищами панкреонекрозу як наступний етап хірургічного лікування (step-up підхід) проводили дилатацію існуючих каналів з використанням бужів і виконували некрсеквестректомію під візуальним контролем через нефроскоп (пат. України 28320). У 2 хворих контрольної групи та в 1 - основної як перший етап хірургічного лікування застосована селективна транслюмбальна відеоконтрольована заочеревинна санація патологічного вогнища з використанням нефроскопа. За неефективності черезшкірних втручань виконували наступний етап лікування - малотравматичні операції: мінілапаротомію - у 3 пацієнтів контрольної групи, мінілюмботомію - у 2 хворих контрольної та в 1 - основної групи. Необхідність виконання відкритої некрсеквестректомії виникла у 28 (37,8\%) пацієнтів контрольної групи та у 2 (8,7\%) основної ( $<<0,05)$, у яких патологічні вогнища не зменшувалися, встановлені дренажі не забезпечували адекватне відходження некротизованих тканин, зберігали ОН та ознаки ССЗВ. При використанні комбінованого відеоендоскопічно-черезшкірного доступу перебіг післяопераційного періоду був неускладненим, всі пацієнти основної групи одужали, тривалість лікування в стаціонарі становила в середньому (27 \pm 4$)$ дня, кількість інвазивних втручань - 1,35 \pm 0,17. У контрольній групі померли 2 хворих (смертність 2,7\%, p > 0,05), тривалість лікування в стаціонарі становила $(32 \pm 2)$ дня ( $>0,05)$, кількість діапевтичних втручань $-2,46 \pm 0,14(\mathrm{p}<0,05)$.

\section{Обговорення}

Більшості пацієнтів з приводу інфікованого ГНП показане виконання хірургічних інвазивних втручань для санації патологічних вогнищ, оскільки тільки консервативне лікування недостатньо ефективне [3 - 5]. За даними літератури, черезшкірні та ендоскопічні мініінвазивні втручання мають переваги порівняно з відкритою некрсеквестректомією, оскільки супроводжуються вірогідно меншою частотою виникнення ОН після операції $[9,10]$. У нашому дослідженні не спостерігали інтра- та післяопераційних ускладнень, пов'язаних з виконанням діапевтичних втручань. Показаннями до здійснення селективної мінілапаромії чи мінілюмботомії були наявність відмежованих, локалізованих інфікованих скупчень рідини, вогнищ інфікованого панкреонекрозу, інфікованих секвестрів ПЗ та парапанкреатичної клітковини, абсцесів ПЗ та заочеревинного простору [3]. Мінілапаротомію виконували в лівій і правій підребрових ділянках з використанням трансректального та па- раректального доступів, по серединній лінії в надчеревній ділянці. Мінілюмботомію виконували переважно по передній та середній пахвових лініях. Якщо, незважаючи на застосування комплексної консервативної терапії, лапароскопії, ендоскопічних, черезшкірних методів хірургічного лікування, «відкритих» мінідоступів, захворювання прогресувало або відзначали його редуковані фази з швидким утворенням заочеревинного нагноєння, збільшенням тяжкості інтоксикації, появою хірургічних ускладнень, переходили до наступного етапу лікування, а саме: виконання широкої лапаротомії, релапаротомії, іноді - програмованого лаважу черевної порожнини. Відкриту некрсеквестректомію застосовували у пацієнтів за більш тяжкого перебігу інфікованого ГНП $\left(\chi^{2}=35,0, \mathrm{p}<0,05\right)$, поширеного некрозу П3 $\left(\chi^{2}=23,2, \mathrm{p}<\right.$ 0,05), неефективності емпіричної антибактеріальної терапії $\left(\chi^{2}=8,3, \mathrm{p}<0,05\right)$, при необхідності раннього дренування (до 4 тиж.) патологічних вогнищ під контролем УЗД $\left(\chi^{2}=5,8, \mathrm{p}<0,05\right)$. Застосування мініінвазивних втручань дозволило відтермінувати виконання оперативного втручання до 25-30-ї доби захворювання в усіх пацієнтів основної групи та у 82,7\% - контрольної, що дало можливість стабілізувати стан хворих, провести передопераційну корекцію ОН, сприяло відмежуванню патологічного вогнища.

\section{Висновки}

1. Використання комбінованого відеоендоскопічночерезшкірного доступу в хірургічному лікуванні інфікованого ГНП забезпечило зменшення частоти виконання широкої (лапаротомної) некрсеквестректомії на 29,1\% ( $\mathrm{p}<0,05)$ порівняно 3 черезшкірними втручаннями під контролем УЗД, що сприяло зменшенню необхідності здійснення інвазивних втручань на 46,1\% (р < 0,05), тривалості лікування в стаціонарі на 5 днів (р > 0,05), летальності - на 2,9\% (p > 0,05).

2. Пріоритетне застосування мініінвазивних діапевтичних втручань в етапному хірургічному лікуванні інфікованого ГНП дозволило відтермінувати виконання відкритої некрсеквестректомії на 4 тиж від початку захворювання у 83,4\% пацієнтів, що сприяло зменшенню післяопераційної летальності до 6,7\%.

\section{References}

1. Peery AF, Dellon ES, Lund J, Crockett SD, McGowan CE, Bulsiewicz WJ, et al. Burden of gastrointestinal disease in the United States: 2012 update. Gastroenterology. 2012 Nov;143(5):1179-87.

2. Phillip V, Steiner JM, Algül H. Early phase of acute pancreatitis: assessment and management. World J Gastrointest Pathophys. 2014 May; 5(3):158-64.

3. Alsfasser G, Schwandner F, Pertschy A, Hauenstein K, Foitzik T, Klar E. Treatment of necrotizing pancreatitis: redefining the role of surgery. World J Surg. 2012 Oct;36(5):1142-7.

4. Poves I, Burdio F, Dorcaratto D, Grande L. Minimally invasive techniques in the treatment of severe acute pancreatitis. Cent Eur J Med. 2014 Aug; 9(4):580-5.

5. Busquets J, Pelaez N, Secanella L. Evolution and results of the surgical management of 143 cases of severe acute pancreatitis in areferral center. Cir Esp. 2014 Sept;92(9):595-603.

6. Working Group IAP/APA Acute Pancreatitis Guidelines. IAP/APA evidence-based guidelines for the management of acute pancreatitis. Pancreatology. 2013 Jun;13 suppl. 1:1-15.

7. Tenner S, Baillie J, DeWitt J, Vege SS. American College of Gastroenterology guideline: management of acute pancreatitis. Am J Gastroen- 
terol. 2013 Jul;108(6):1400-16.

8. Banks PA, Bollen TL, Dervenis C, Gooszen HG, Johnson CD, Sarr MG, et al. Classification of acute pancreatitis 2012: revision of the Atlanta classification and definitions by international consensus. Gut. 2013 Jan;62(1):102-11.

9. Bakker OJ, van Santvoort HC, van Brunschot S, Geskus RB, Besselink MG, Bollen TL, et al. Endoscopic transgastric versus surgical necrosectomy for infected necrotizing pancreatitis: a randomized trial. JAMA 2012 Mar;307(10):1084-5.

10. Khomiak IV, Rotar OV, Tereshkevych IS, Rotar VI, Khomiak AI, Taneja KS. Comparison of open pancreatic necrosectomy with stepup minimally invasive approach as surgical treatment of patients with acute necrotizing pancreatitis. Int Surg J. 2017 Aug;4(8):2502-6. 